\title{
Conditions potentially sensitive to a Personal Health Record (PHR) intervention, a systematic review
}

\author{
Morgan Price ${ }^{1,2,3^{*}}$, Paule Bellwood ${ }^{2}$, Nicole Kitson ${ }^{2}$, Iryna Davies ${ }^{1}$, Jens Weber ${ }^{1,2,3}$ and Francis Lau ${ }^{2}$
}

\begin{abstract}
Background: Personal Health Records (PHRs) are electronic health records controlled, shared or maintained by patients to support patient centered care. The potential for PHRs to transform health care is significant; however, PHRs do not always achieve their potential. One reason for this may be that not all health conditions are sensitive to the PHR as an intervention. The goal of this review was to discover which conditions were potentially sensitive to the PHR as an intervention, that is, what conditions have empirical evidence of benefit from PHR-enabled management.

Methods: A systematic review of Medline and CINAHL was completed to find articles assessing PHR use and benefit from 2008 to 2014 in specific health conditions. Two researchers independently screened and coded articles. Health conditions with evidence of benefit from PHR use were identified from the included studies.

Results: 23 papers were included. Seven papers were RCTs. Ten health conditions were identified, seven of which had documented benefit associated with PHR use: asthma, diabetes, fertility, glaucoma, HIV, hyperlipidemia, and hypertension. Reported benefits were seen in terms of care quality, access, and productivity, although many benefits were measured by self-report through quasi-experimental studies. No study examined morbidity/mortality. No study reported harm from the PHR.

Conclusion: There is a small body of condition specific evidence that has been published. Conditions with evidence of benefit when using PHRs tended to be chronic conditions with a feedback loop between monitoring in the PHR and direct behaviours that could be self-managed. These findings can point to other potentially PHR sensitive health conditions and guide PHR designers, implementers, and researchers. More research is needed to link PHR design, features, adoption and health outcomes to better understand how and if PHRs are making a difference to health outcomes.
\end{abstract}

Keywords: Personal health records, Patient portals, Self-management, Systematic review, Chronic disease management

\section{Background}

\section{Personal health records}

Personal Health Records (PHRs) are electronic health records controlled, shared, or maintained by patients to support patient centered care [1]. While PHRs have variable designs and features, they share a similar goal of improving patient engagement in their care. PHR enabled management can include both self-management and communication with members of the patients' circles of care. PHRs can be standalone or tethered to

\footnotetext{
* Correspondence: morgan@leadlab.ca

'Department of Family Practice, University of British Columbia, Vancouver, B.C., Canada

${ }^{2}$ Health Information Science, University of Victoria, Victoria, B.C., Canada

Full list of author information is available at the end of the article
}

another clinical information system such as a hospital information system or part of a regional electronic health record. PHR features can range from administrative (e.g. booking appointments and paying bills) to more clinical features (e.g. reviewing information, communicating with the care team, documenting care activities/results/ outcomes). The potential for PHRs to reduce care costs and increase access to care is significant and it has been suggested that PHRs will help enable and empower patients $[2,3]$. However, despite millions of dollars spent on PHRs, the published evidence and research on PHRs is relatively limited $[4,5]$, and, compared to the promises, adoption rates continue to be lower than hoped [6]. 
The evidence for benefit of PHRs is mixed [7]. There has been early positive evidence as well as dramatic challenges in adoption of PHRs [8]. Potential benefits of PHRs include improvement in: quality, access, and costs [9]. Stakeholders (e.g. patients, providers, payers) will experience benefits differently [10]. Several reviews have looked at aspects of PHRs and PHR features such as: benefit of secure messaging [11], medication adherence reminders [12], or symptom reporting [13]. Others examined effect on chronic diseases [7] or mental health [14]. The challenges to achieving PHR benefits include: poor adoption rates [6], poor integration into care processes [15], and policy limitations [16]. More work is needed to understand how PHRs can be meaningfully used [5] and how PHRs can support select patient populations with specific conditions.

The variable benefits seen with PHRs are due to a number of factors. The PHR Adoption Model describes four factors that can influence behavior which may lead to outcome changes: personal factors, technology factors, environmental factors, and chronic disease factors [6]. It highlights chronic disease factors as an important aspect of adoption of PHRs. That is, the nature of the chronic condition the patient has impacts adoption and value of the PHR.

For this paper we sought to discover which health conditions have been assessed for improvements in outcomes that correlate with PHR use. There has been a recent review of PHRs and chronic disease [5] but there has not been a review to examine which conditions have evidence of benefit from PHR use. A condition is an aspect of a person's health including a symptom, illness, diagnosis, or health goal. Benefits could be considered for the person, the care team (both formal and informal), or the overall healthcare system.

\section{Objectives of this paper}

The purpose of this paper is to add to our shared knowledge on PHRs by systematically reviewing the literature to develop an evidence-based list of conditions that have evidence of improvements that correlate with PHR use. We seek to answer the following questions:

1. What health conditions have evidence for benefits of PHR enabled self-management?

2. What are the common care activities related to these conditions that are supported through the use of PHR?

3. Can we use these characteristics to predict other potentially PHR sensitive conditions?

\section{Methods}

\section{Evidence collection}

Medline and CINAHL were searched for articles from 2008 to 2014. This focused findings on technically more modern PHRs (e.g. potential for mobile user experiences, more advanced web interactions). Search terms used: Personal Health Record or Patient Portal in the Title or Abstract. We limited our search to English language and abstract availability. Ethics was not required for this systematic review.

\section{Study selection and inclusion/exclusion criteria}

Inclusion criteria were:

1. Use of terms personal health record, patientcontrolled electronic health record, or patient portal in the title or abstract; and

2. Conditions or self-care activities; and

3. Evidence of actual use of PHR in specific conditions

4. Use of PHR in outpatient environment

5. Only primary studies were included that assessed benefit of PHRs by patients for those chronic conditions.

As we were seeking to find empirical evidence of PHR use and benefit, we excluded studies that did not have patients using PHRs (e.g. surveys on intention to use) or studies that were based only on usability testing. Further studies that assessed training effectiveness, or studies that only measured PHR use without looking at impact were excluded. We excluded any opinion, commentary, reviews, or theoretical PHR papers. Papers that evaluated electronic health records without focusing on PHR were also excluded.

Article selection occurred in two passes. First, the Titles/ Abstracts were screened; the full text papers were pulled for those that passed initial screening for full review. Both screening and full text review were completed independently by two of the authors.

\section{Evidence synthesis}

Two authors coded the included articles independently. The papers were graded using an extended evidence hierarchy based on Australia's National Health and Medical Research Council (NHMRC) evidence hierarchy (Figure 1) [17]. Data was extracted from the papers including: type of PHR, patient population, health condition(s) examined, self-care activities, PHR features, and benefits observed (if any) as determined by the researcher. The codes were then compared. Consensus was reached on the coding for each characteristic. A third author was available for mediation if consensus could not be reached. The original authors, not the reviewers, determined benefits.

\section{Results}

\section{Evidence of PHR benefit}

Our search followed PRISMA guidelines (Figure 2) found 564 unique records, of which 23 met inclusion criteria 


\begin{tabular}{|c|c|c|}
\hline & Lev & Evidence from: \\
\hline & & Systematic Review of RTCs \\
\hline & II & At least one proper RCT \\
\hline$\frac{0}{2}$ & III-1 & Pseudorandomized trial \\
\hline 苑 & III-2 & Comparative Studies \\
\hline 离 & III-3 & $\begin{array}{l}\text { Comparative Studies with } \\
\text { historical control }\end{array}$ \\
\hline$\underline{\underline{o}}$ & IV & $\begin{array}{l}\text { Case Series and studies } \\
\text { without control (pre/post, } \\
\text { post only) }\end{array}$ \\
\hline & & vidence hierarchy [17]. \\
\hline
\end{tabular}

and examined a specific health condition. Two papers $[18,19]$ each examined three specific conditions and were included. Within the 23 studies, there were seven randomized control trials, the rest were quasi-experimental or observational studies. Most studies were small and/or of short duration with no prospective study lasting more than one year. The metrics examined varied between studies such that comparison was difficult. 12 studies looked at self-reported data alone, with six studies using at least one previously validated instrument. Nine of the included studies looked at condition specific indicators such as A1c, LDL, plasma HIV-1 RNA, and blood pressure. These were tracked through chart reviews or electronic record reporting tools. The included studies are summarized in Table 1.

\section{Health conditions evaluated}

Ten health conditions were found in the included studies (Table 1). Seven of these ten health conditions had at least one study reporting benefit from the use of a PHR: asthma, diabetes, fertility, glaucoma, HIV, hyperlipidemia, and hypertension. Diabetes was the most studied condition with eleven of twelve studies showing benefit. Three conditions had studies that meth the criteria but did not show benefit of the PHR: cancer, idiopathic thrombocytopenic purpura (ITP), and multiple sclerosis.

PHR supported care activities and PHR characteristics $74 \%$ (17/23) studies used tethered PHRs, connected to regional electronic medical records/electronic health records. 76\% (13/17) studies that used tethered PHRs

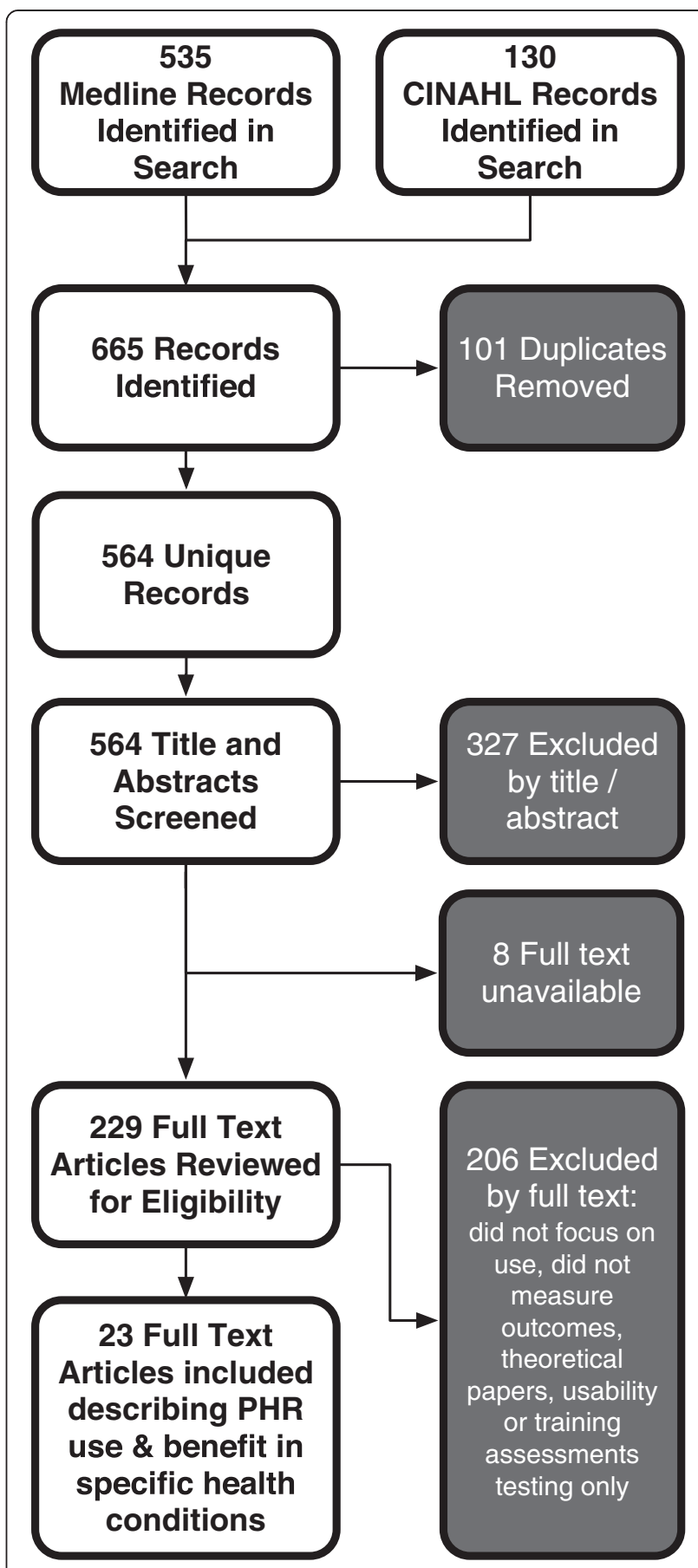

Figure 2 Literature Review Strategy, based on PRIMSA.

reported benefit. In comparison, only 50\% (3/6) studies that used standalone PHRs showed benefit.

Studies described a set of PHR supported care activities that included the following:

- Access Own Health Data - Using the PHR to access shared clinical records. This could include view only (e.g. lab results) or editing/annotating. 
Table 1 Summary of included primary PHR studies that measured benefit from use of PHR by patients

\begin{tabular}{|c|c|c|c|c|c|c|c|c|c|}
\hline Author & Conditions & Benefit & Level & \# of patients & $\begin{array}{l}\text { Study design } \\
\text { and duration }\end{array}$ & Location & PHR type and features & Evaluation methods & $\begin{array}{l}\text { Reported } \\
\text { Benefits }\end{array}$ \\
\hline Wiljer, 2010 [33] & Cancer & No & IV & $\begin{array}{l}320 \text { consented, } \\
114 \text { completed } \\
\text { study }\end{array}$ & 6 weeks & Canada & $\begin{array}{l}\text { Tethered PHR with access } \\
\text { to personal health data } \\
\text { (labs and diagnostic imaging), } \\
\text { access to support groups and } \\
\text { a virtual librarian. }\end{array}$ & $\begin{array}{l}\text { State-Trait Anxiety } \\
\text { Inventory; Stanford } \\
\text { Self-Efficacy for } \\
\text { Managing Chronic } \\
\text { Disease }\end{array}$ & No change \\
\hline \multirow[t]{4}{*}{ Wade-Vuturo, 2013 [34] } & \multirow[t]{4}{*}{ Diabetes } & \multirow[t]{4}{*}{ Yes } & \multirow[t]{4}{*}{ IV } & \multirow[t]{4}{*}{54 patients } & \multirow[t]{4}{*}{$\begin{array}{l}\text { Crossectional: } \\
\text { PHR use }>1 \text { year } \\
\text { in } 43 \text { patients }\end{array}$} & \multirow[t]{4}{*}{ USA } & \multirow[t]{4}{*}{$\begin{array}{l}\text { Tethered Portal with secure } \\
\text { messaging, access to medical } \\
\text { records }\end{array}$} & \multirow[t]{4}{*}{$\begin{array}{l}\text { Patient Self-Report; } \\
\text { Chart review to assess } \\
\text { glycemic control (A1c). }\end{array}$} & $\begin{array}{l}\text { Improved } \\
\text { Patient } \\
\text { Satisfaction } \\
\text { with Care }\end{array}$ \\
\hline & & & & & & & & & $\begin{array}{l}\text { Improved } \\
\text { Disease Control }\end{array}$ \\
\hline & & & & & & & & & $\begin{array}{l}\text { More effective } \\
\text { face-to-face } \\
\text { visits }\end{array}$ \\
\hline & & & & & & & & & $\begin{array}{l}\text { Better Pt- } \\
\text { Provider } \\
\text { Communication }\end{array}$ \\
\hline \multirow[t]{4}{*}{ Urowitz, 2012 [21] } & \multirow[t]{4}{*}{ Diabetes } & \multirow[t]{4}{*}{ Yes } & \multirow[t]{4}{*}{ IV } & \multirow[t]{4}{*}{17 patients } & \multirow[t]{4}{*}{$\begin{array}{l}\text { Crossectional, } \\
\text { at least } 6 \text { months } \\
\text { of access to PHR }\end{array}$} & \multirow[t]{4}{*}{ Canada } & \multirow{4}{*}{$\begin{array}{l}\text { Standalone PHR with ability } \\
\text { to record personal health } \\
\text { information and see trends, } \\
\text { can also look up health } \\
\text { information references. }\end{array}$} & \multirow[t]{4}{*}{ Patient Self-Report } & $\begin{array}{l}\text { Improved } \\
\text { Access to own } \\
\text { information }\end{array}$ \\
\hline & & & & & & & & & $\begin{array}{l}\text { Improved } \\
\text { access to pt } \\
\text { information by } \\
\text { provider }\end{array}$ \\
\hline & & & & & & & & & $\begin{array}{l}\text { Improved } \\
\text { ability to self } \\
\text { manage }\end{array}$ \\
\hline & & & & & & & & & $\begin{array}{l}\text { More Activated } \\
\text { Patient }\end{array}$ \\
\hline Tenforde, 2011 [35] & Diabetes & Yes & IV & $\begin{array}{l}10,746 \text { adult } \\
\text { patients }\end{array}$ & $\begin{array}{l}\text { Retrospective audit } \\
\text { over } 12 \text { months }\end{array}$ & USA & $\begin{array}{l}\text { Tethered PHR with secure } \\
\text { messaging and access to } \\
\text { health record data, reminders } \\
\text { for follow up and health } \\
\text { information }\end{array}$ & $\begin{array}{l}\text { Chart review for } \\
\text { diabetes indicators } \\
\text { (A1c, LDL-C, BP, BMI). }\end{array}$ & $\begin{array}{l}\text { Improved } \\
\text { Disease Control }\end{array}$ \\
\hline \multirow[t]{2}{*}{ Wald, 2010 [36] } & \multirow[t]{2}{*}{ Diabetes } & \multirow[t]{2}{*}{ Yes } & \multirow[t]{2}{*}{$\|$} & \multirow[t]{2}{*}{2027 patients } & \multirow[t]{2}{*}{$\begin{array}{l}\text { prompt } 3 \text { weeks } \\
\text { prior to encounter. }\end{array}$} & \multirow[t]{2}{*}{ USA } & \multirow[t]{2}{*}{$\begin{array}{l}\text { Tethered PHR with secure } \\
\text { messaging, access to health } \\
\text { record data, Journal, and } \\
\text { health information. }\end{array}$} & \multirow[t]{2}{*}{$\begin{array}{l}\text { Patient and Provider } \\
\text { Self Report }\end{array}$} & $\begin{array}{l}\text { Improved } \\
\text { Patient } \\
\text { Satisfaction } \\
\text { with Care }\end{array}$ \\
\hline & & & & & & & & & $\begin{array}{l}\text { Improved } \\
\text { access to pt } \\
\text { information by } \\
\text { provider }\end{array}$ \\
\hline
\end{tabular}




\begin{tabular}{|c|c|c|c|c|c|c|c|c|c|}
\hline & & & & & & & & & $\begin{array}{l}\text { More effective } \\
\text { face-to-face } \\
\text { visits }\end{array}$ \\
\hline & & & & & & & & & $\begin{array}{l}\text { More Activated } \\
\text { Patient }\end{array}$ \\
\hline Hess, 2014 [37] & $\begin{array}{l}\text { Diabetes (able to } \\
\text { extract from paper) }\end{array}$ & Yes & IV & 504 patients & Pre post, one year & USA & $\begin{array}{l}\text { Tethered PHR with } \\
\text { reminders for preventive care }\end{array}$ & $\begin{array}{l}\text { Patient documentation } \\
\text { of care received }\end{array}$ & $\begin{array}{l}\text { Improved } \\
\text { Disease Control }\end{array}$ \\
\hline Fonda, 2009 [38] & Diabetes & Yes & $\|$ & 104 patients & RCT, 52 weeks & USA & $\begin{array}{l}\text { Tethered PHR with secure } \\
\text { messaging, access to personal } \\
\text { health data, educational materials. }\end{array}$ & $\begin{array}{l}\text { Problem Areas in } \\
\text { Diabetes (PAID) } \\
\text { validated survey }\end{array}$ & $\begin{array}{l}\text { Decreased } \\
\text { Patient Distress }\end{array}$ \\
\hline Lau, 2014 [39] & Diabetes & Yes & || $1-3$ & $\begin{array}{l}50 \text { users and } \\
107 \text { non-users }\end{array}$ & 6-24 months & Canada & $\begin{array}{l}\text { Standalone PHR with health } \\
\text { information, journaling, entering } \\
\text { health data, secure messaging } \\
\text { with providers }\end{array}$ & $\begin{array}{l}\text { Chart review to monitor } \\
\text { A1c control }\end{array}$ & $\begin{array}{l}\text { Improved } \\
\text { Disease Control }\end{array}$ \\
\hline Sarkar, 2014 [40] & Diabetes & Yes & || $\mid-3$ & $\begin{array}{l}8705 \text { users } \\
\text { with } 9055 \\
\text { matched } \\
\text { reference } \\
\text { group }\end{array}$ & $\begin{array}{l}\text { Observational } \\
\text { cohort study, } 1 \text { year }\end{array}$ & USA & $\begin{array}{l}\text { Tethered PHR with access to } \\
\text { record, secure messaging, renewal } \\
\text { requests, and online scheduling. }\end{array}$ & $\begin{array}{l}\text { Measured renewal rates } \\
\text { for statins over } 1 \text { year } \\
\text { based on chart data }\end{array}$ & $\begin{array}{l}\text { Improved } \\
\text { Disease Control }\end{array}$ \\
\hline \multirow[t]{3}{*}{ Wald, 2009 [41] } & \multirow[t]{3}{*}{ Diabetes } & \multirow[t]{3}{*}{ Yes } & \multirow[t]{3}{*}{ IV } & \multirow[t]{3}{*}{37 patients } & \multirow[t]{3}{*}{$\begin{array}{l}2 \text { week follow up, } \\
\text { patients were } \\
\text { already using the } \\
\text { general PHR as part } \\
\text { of inclusion. }\end{array}$} & \multirow[t]{3}{*}{ USA } & \multirow[t]{3}{*}{$\begin{array}{l}\text { Tethered PHR with secure } \\
\text { messaging, access to personal } \\
\text { health data, decision support, } \\
\text { ability to annotate their health } \\
\text { record, care plan. }\end{array}$} & \multirow[t]{3}{*}{ Self Report } & $\begin{array}{l}\text { Improved } \\
\text { access to pt } \\
\text { information by } \\
\text { provider }\end{array}$ \\
\hline & & & & & & & & & $\begin{array}{l}\text { More effective } \\
\text { face-to-face } \\
\text { visits }\end{array}$ \\
\hline & & & & & & & & & $\begin{array}{l}\text { Better Pt-Provider } \\
\text { Communication }\end{array}$ \\
\hline Grant, 2008 [20] & Diabetes & No & $\|$ & 244 patients & $\begin{array}{l}\text { RCT, use of PHR } \\
52 \text { weeks }\end{array}$ & USA & $\begin{array}{l}\text { Tethered PHR with access } \\
\text { to personal health data, } \\
\text { decision support, care plans }\end{array}$ & $\begin{array}{l}\text { DM indicators: BP control, } \\
\text { A1c, LDL-C' \# of primary } \\
\text { care visits. }\end{array}$ & No change \\
\hline \multirow[t]{3}{*}{ van Empel, 2011 [42] } & \multirow[t]{3}{*}{ Fertility } & \multirow[t]{3}{*}{ Yes } & \multirow[t]{3}{*}{ IV } & \multirow[t]{3}{*}{369 couples } & \multirow[t]{3}{*}{$\begin{array}{l}\text { Cross sectional } \\
\text { survey }\end{array}$} & \multirow[t]{3}{*}{ Netherlands } & \multirow{3}{*}{$\begin{array}{l}\text { Tethered PHR with secure } \\
\text { messaging, access to } \\
\text { personal health data, } \\
\text { social support/forums. }\end{array}$} & \multirow[t]{3}{*}{$\begin{array}{l}\text { Patient Self-Report, } \\
\text { Partner Self-Report }\end{array}$} & $\begin{array}{l}\text { Improved } \\
\text { Continuity }\end{array}$ \\
\hline & & & & & & & & & $\begin{array}{l}\text { Improved access } \\
\text { to health } \\
\text { knowledge }\end{array}$ \\
\hline & & & & & & & & & $\begin{array}{l}\text { Better Pt-Provider } \\
\text { Communication }\end{array}$ \\
\hline Boland 2014 [43] & Glaucoma & Yes & $\|$ & $\begin{array}{l}38 \text { intervention; } \\
32 \text { control }\end{array}$ & $\mathrm{RCT} ; 3$ months & USA & $\begin{array}{l}\text { PHR that could record } \\
\text { patient information and } \\
\text { medications; daily reminders } \\
\text { by text/phone to intervention } \\
\text { group to take medication }\end{array}$ & $\begin{array}{l}\text { Adherence monitoring } \\
\text { with medication smart } \\
\text { cap, patient surveys. }\end{array}$ & $\begin{array}{l}\text { Improved } \\
\text { medication } \\
\text { management }\end{array}$ \\
\hline Crouch, 2014 [44] & HIV & Yes & || $\mid-3$ & & Cross sectional & USA & & & \\
\hline
\end{tabular}


Table 1 Summary of included primary PHR studies that measured benefit from use of PHR by patients (Continued)

\begin{tabular}{|c|c|c|c|c|c|c|c|c|c|}
\hline & & & & \multirow{2}{*}{\multicolumn{3}{|c|}{$\begin{array}{l}40 \text { (20 users, } \\
20 \text { non-users) }\end{array}$}} & \multirow{2}{*}{$\begin{array}{l}\text { Tethered PHR with access to } \\
\text { labs, notes, secure communication } \\
\text { and medication renewal. }\end{array}$} & \multirow[t]{2}{*}{$\begin{array}{l}\text { Patient Activation } \\
\text { Measure }\end{array}$} & $\begin{array}{l}\text { More Activated } \\
\text { Patient }\end{array}$ \\
\hline & & & & & & & & & $\begin{array}{l}\text { Improved } \\
\text { Disease Control }\end{array}$ \\
\hline \multirow[t]{3}{*}{ Gordon, 2012 [45] } & \multirow[t]{3}{*}{ HIV } & \multirow[t]{3}{*}{ No } & \multirow[t]{3}{*}{ IV } & \multirow[t]{3}{*}{$\begin{array}{l}112 \text { active } \\
\text { users }\end{array}$} & \multirow[t]{3}{*}{$\begin{array}{l}\text { Survey, access up to } \\
114 \text { weeks }\end{array}$} & \multirow[t]{3}{*}{ USA } & \multirow[t]{3}{*}{$\begin{array}{l}\text { Tethered PHR viewer with } \\
\text { access to personal health data. }\end{array}$} & \multirow[t]{3}{*}{ Patient-Self Report } & $\begin{array}{l}\text { Improved Access } \\
\text { to own } \\
\text { information }\end{array}$ \\
\hline & & & & & & & & & $\begin{array}{l}\text { Improved access } \\
\text { to health } \\
\text { knowledge }\end{array}$ \\
\hline & & & & & & & & & $\begin{array}{l}\text { More Activated } \\
\text { Patient }\end{array}$ \\
\hline \multirow[t]{3}{*}{ Kahn, 2010 [46] } & \multirow[t]{3}{*}{ HIV } & \multirow[t]{3}{*}{ Yes } & \multirow[t]{3}{*}{ IV } & \multirow[t]{3}{*}{$\begin{array}{l}221 \text { users } \\
\text { registered }\end{array}$} & \multirow{3}{*}{$\begin{array}{l}\text { cross sectional } \\
\text { survey, access to } \\
\text { PHR up to } \\
21 \text { months }\end{array}$} & \multirow[t]{3}{*}{ USA } & \multirow{3}{*}{$\begin{array}{l}\text { Tethered PHR with access to } \\
\text { personal health data, ability to } \\
\text { record own health data, access } \\
\text { health information }\end{array}$} & \multirow[t]{3}{*}{ Patient Self-Report } & $\begin{array}{l}\text { Better Pt-Provider } \\
\text { Communication }\end{array}$ \\
\hline & & & & & & & & & $\begin{array}{l}\text { Improved ability } \\
\text { to self manage }\end{array}$ \\
\hline & & & & & & & & & $\begin{array}{l}\text { More Activated } \\
\text { Patient }\end{array}$ \\
\hline McInnes, 2013 [47] & HIV & Yes & IV & 1871 patients & $\begin{array}{l}\text { Cross sectional } \\
\text { survey and chart } \\
\text { review }\end{array}$ & USA & $\begin{array}{l}\text { Tethered PHR with access to } \\
\text { personal health data, request } \\
\text { medication renewal, reminders } \\
\text { for preventive care, scheduling } \\
\text { appointments, secure messaging }\end{array}$ & $\begin{array}{l}\text { Chart review, survey } \\
\text { data from Veterans } \\
\text { Aging Cohort Study }\end{array}$ & $\begin{array}{l}\text { Improved ability } \\
\text { to self manage }\end{array}$ \\
\hline \multirow[t]{2}{*}{ Shade, 2014 [48] } & \multirow[t]{2}{*}{ HIV } & \multirow[t]{2}{*}{ Yes } & \multirow[t]{2}{*}{ IV } & \multirow[t]{2}{*}{$\begin{array}{l}\text { Unclear at site } \\
\text { using PHR }\end{array}$} & \multirow[t]{2}{*}{$\begin{array}{l}12 \text { month ( } 6 \text { pre } \\
\text { and } 6 \text { post) study }\end{array}$} & \multirow[t]{2}{*}{ USA } & \multirow{2}{*}{$\begin{array}{l}\text { Standalone PHR with continuity } \\
\text { of care patient summaries including } \\
\text { HIV results; secure provider } \\
\text { communication. }\end{array}$} & \multirow[t]{2}{*}{ Chart review } & $\begin{array}{l}\text { Improved ability } \\
\text { to self manage }\end{array}$ \\
\hline & & & & & & & & & $\begin{array}{l}\text { Improved } \\
\text { Disease Control }\end{array}$ \\
\hline Wagner, 2012 [49] & Hypertension & No & $\|$ & 453 users & $\begin{array}{l}\text { RCT, PHR use up to } \\
39 \text { weeks (4 visits) }\end{array}$ & USA & $\begin{array}{l}\text { Tethered PHR with secure messaging, } \\
\text { access to personal health data, track } \\
\text { personal health data, access to health } \\
\text { information, care plan goal setting. }\end{array}$ & $\begin{array}{l}\text { Patient Self-Report, Chart } \\
\text { review for blood pressure }\end{array}$ & No change \\
\hline Chiche, 2012 [50] & $\begin{array}{l}\text { Idiopathic } \\
\text { thrombocytopenic } \\
\text { purpura (ITP) }\end{array}$ & No & || $\mid-2$ & 43 patients & 26 weeks & France & $\begin{array}{l}\text { Standalone PHR with ability to } \\
\text { record personal health data }\end{array}$ & $\begin{array}{l}\text { ITP patient assessment } \\
\text { questionnaire }\end{array}$ & No change \\
\hline \multirow[t]{2}{*}{ Miller, 2011 [51] } & \multirow[t]{2}{*}{ Multiple Sclerosis } & \multirow[t]{2}{*}{ No } & \multirow[t]{2}{*}{$\|$} & \multirow[t]{2}{*}{$\begin{array}{l}204 \text { patients } \\
\text { recruited }\end{array}$} & \multirow[t]{2}{*}{ RCT, 52 weeks } & \multirow[t]{2}{*}{ USA } & $\begin{array}{l}\text { Standalone PHR with ability to } \\
\text { record personal health data and } \\
\text { receive decision support } \\
\text { (through MS Quality of Life Inventory) }\end{array}$ & $\begin{array}{l}\text { Sickness Impact Profile, } \\
\text { MS Functional } \\
\text { Composite, Control } \\
\text { Subscale of the MS } \\
\text { Self-Efficacy Scale }\end{array}$ & No change \\
\hline & & & & & & & & $\begin{array}{l}\text { Seniors' General } \\
\text { Satisfaction and } \\
\text { Physician Quality } \\
\text { of Care }\end{array}$ & \\
\hline
\end{tabular}


Table 1 Summary of included primary PHR studies that measured benefit from use of PHR by patients (Continued)

\begin{tabular}{|c|c|c|c|c|c|c|c|c|c|}
\hline & & & & & & & & Euro-Quality of Life 5 & \\
\hline \multirow[t]{2}{*}{ Solomon, 2012 [18] } & \multirow[t]{2}{*}{$\begin{array}{l}\text { Asthma, } \\
\text { Hypertension, } \\
\text { Diabetes }\end{array}$} & \multirow[t]{2}{*}{ Yes } & \multirow[t]{2}{*}{$\|$} & \multirow[t]{2}{*}{201 patients } & \multirow[t]{2}{*}{12 week } & \multirow[t]{2}{*}{ USA } & \multirow[t]{2}{*}{$\begin{array}{l}\text { Tethered PHR with secure messaging } \\
\text { and targeted health education weekly } \\
\text { training modules. }\end{array}$} & $\begin{array}{l}\text { Patient Activation } \\
\text { Measure } 13 \text { (PAM-13) }\end{array}$ & $\begin{array}{l}\text { Improved } \\
\text { ability to self } \\
\text { manage }\end{array}$ \\
\hline & & & & & & & & Chart Review & $\begin{array}{l}\text { More Activated } \\
\text { Patient }\end{array}$ \\
\hline \multirow[t]{2}{*}{ Sobko, 2011 [19] } & \multirow{2}{*}{$\begin{array}{l}\text { Diabetes, } \\
\text { hypertension, } \\
\text { lipids }\end{array}$} & \multirow[t]{2}{*}{ Yes } & \multirow[t]{2}{*}{ IV } & \multirow[t]{2}{*}{9504} & \multirow{2}{*}{$\begin{array}{l}\text { Cohort study - chart } \\
\text { review } 6 \text { month pre } \\
\text { and } 14 \text { months post } \\
\text { PHR deployment }\end{array}$} & \multirow[t]{2}{*}{ USA } & \multirow{2}{*}{$\begin{array}{l}\text { Tethered PHR with access to health } \\
\text { record, secure communication, } \\
\text { decision support, medication renewal }\end{array}$} & \multirow{2}{*}{$\begin{array}{l}\text { Chart review: medication } \\
\text { possession rates; A1c, } \\
\text { blood pressure, lipids }\end{array}$} & $\begin{array}{l}\text { Improved ability } \\
\text { to self manage }\end{array}$ \\
\hline & & & & & & & & & $\begin{array}{l}\text { Improved } \\
\text { Disease Control }\end{array}$ \\
\hline
\end{tabular}


- Access Health Information - Using the PHR to access handouts, protocol information or other self-management information in a linked or embedded knowledge base.

- Record Personal Health Data - Using the PHR to record and track subjective experience data or objective data related to the condition over time.

- Receive Personal Decision Support - Using the PHR health data to drive evidence-based reminders and alerts to the user to support self-management.

- Plan Care - Using the PHR to proactively set personal goals, targets and tasks related to health and care. For example: set weight or blood glucose targets.

- Self-Manage Care - Using the PHR to make day-today decisions about care management, such as medication dosing, food choice.

- Communicate with Care Team - Using the PHR to engage with and support members of the circle of care. This can be virtual and/or face-to-face. This includes direct communication (e.g. secure messaging) or sharing of data in a shared repository.

- Communicate with Support Group - Using the PHR platform to securely engage in communication with informal members of the care team or members of a community for support. Using a secure forum to discuss health related issues.

Table 2 highlights the types of PHR features that were reported by the conditions in studies where benefits were reported. Most reported using PHRs that provided patients with access to general health information $(5 / 6$ conditions) and improved communication with their provider(s) (4/6 conditions). Access to personal health data and ability to record or annotate against that data were supported for $3 / 6$ conditions.

No study described a PHR platform that included all eight features. Both positive and negative PHR studies described PHR platforms with various combinations of these features (see Table 1). It was not clear from many of the papers how these features were designed or implemented in the context of the healthcare system.

\section{Benefits and harm of PHR use}

$70 \%$ of studies $(16 / 23)$ reported benefits associated with PHR use. Of the 16 studies that reported benefit, six were based only on self-reported data (or provider or partner reported) and not on objective data or a validated reporting tool. Of the six studies that relied on non-validated self-report, $83 \%$ reported benefit $(5 / 6)$. By contrast, only $50 \%(5 / 10)$ of studies that used validated/ objective data reported benefit. 57\% (4/7) of Randomized Control Trials (RCTs) reported benefits although one of the RCTs used self-report data only.

The studies looked at a range of metrics that covered several domains of benefit from disease specific measures to validated surveys to custom surveys. Disease specific outcomes included primarily indicators for diabetes (A1c, LDL, blood pressure, and Body Mass Index) and one for blood pressure in a hypertension study.

One diabetes RCT [20] measured number of primary visits and saw no change with the PHR. Ten validated survey instruments were used across the 23 studies. Five validated survey instruments used were not specific to the health condition being assessed: the Patient Activation Measure, the State-Trait Anxiety Inventory, the Stanford Self-Efficacy for Managing Chronic Disease, Seniors' General Satisfaction, Physician Quality of Care, and the Euro-Quality of Life 5. Five tools were health condition specific: Problem Areas in Diabetes (PAID) Survey (Fonda), ITP patient assessment questionnaire, Sickness Impact Profile, MS Functional Composite, and the Control Subscale of the MS Self-Efficacy Scale. Several studies used non-validated tools to gather targeted self-report data from their participants. Custom surveys examined a range of concepts, including: assessing the PHR components, patient satisfaction, improvements in self-management, access to care, access to information, and sense of control.

The benefits are summarized in Table 3, based on the descriptions by the original authors. The counts exceed the number of studies as studies often assessed and reported on multiple benefits. Most commonly reported benefits included more activated patients, improved ability

Table 2 Summary of reported PHR features by condition

\begin{tabular}{|c|c|c|c|c|c|c|}
\hline PHR Feature & Asthma & Diabetes & Fertility & Glaucoma & HIV & Hypertension \\
\hline Access Medical/Health Record & & $x$ & & & $x$ & \\
\hline Access Health Information & $x$ & $x$ & $x$ & & $x$ & $x$ \\
\hline Record Personal Health Data & & $x$ & & $x$ & $x$ & \\
\hline Annotate Medical/Health Record & & $x$ & & & & \\
\hline Receive Personal Decision Support & & $x$ & & $x$ & & \\
\hline Develop/Manage Care plans & & $x$ & & $x$ & & \\
\hline Communicate with Provider & $x$ & $x$ & $x$ & & & $x$ \\
\hline Communicate with Support Group & & & $x$ & & & \\
\hline
\end{tabular}


Table 3 Summary of reported benefits of PHR for each condition

\begin{tabular}{|c|c|c|c|c|c|c|}
\hline Reported Benefit & Asthma & Diabetes & Fertility & Glaucoma & HIV & Hypertension \\
\hline Improved Patient Satisfaction with Care & & 2 & & & & \\
\hline Improved Disease Control & & 5 & & & 1 & \\
\hline Decreased Patient Distress & & 1 & & & & \\
\hline Improved Continuity & & & 1 & & & \\
\hline Improved medication management & & & & 1 & 1 & \\
\hline Improved Access to own information & & 1 & & & & \\
\hline Improved access to health knowledge & & & 1 & & & \\
\hline Improved access to patient information by provider & & 3 & & & & \\
\hline More effective face-to-face visits & & 3 & & & & \\
\hline Better Patient-Provider Communication & & 2 & 1 & & 1 & \\
\hline Improved ability to self manage & 1 & 1 & & & 3 & 1 \\
\hline More Activated Patient & 1 & 2 & & & 1 & 1 \\
\hline
\end{tabular}

Cell numbers indicate number of studies that measured benefit in that area by health condition.

to self-manage, and improved communication with providers.

No study reported on harm from using the PHR. Providers in one study voiced concern that patients assumed the providers were monitoring the PHR constantly and patients may not report a change in health status as they may assume the provider is aware through the PHR [21].

\section{Discussion}

The intention of this systematic review was to discover from the literature a set of health conditions that were potentially "sensitive" to a PHR as a health intervention. That is, which conditions had empirical evidence that associated PHR use with improved health outcomes. While we found $70 \%$ of the 23 included studies reported benefit, the literature base is still small, with most of the PHR research focusing on intention to use, usability, and use characteristics. Most of the included studies in this review that focused on outcomes were quasi-experimental and focused on shorter-term or self-reported benefits. No study examined morbidity or mortality. Thus, there is a gap in high quality primary PHR research that focuses on longer-term outcome measures. This is somewhat expected, as electronic PHRs are still a relatively new and are rapidly changing. Research is needed to better understand the features of the PHRs and how they are used so that benefits are seen. Additional research is also needed to explore unintended consequences of PHR. None of the included studies assessed potential harms and, as we know from other literature, there can be unintended consequences when using health information systems. This is consistent with Health Information Systems research in general [22,23] and speaks to a greater need in health informatics research. PHRs are socio-technical systems that can change many aspects of care processes as well as care outcomes. Multi-methods research is needed to understand PHR impact and capture some of these unintended consequences. Larger studies are needed that assess sustained benefits of PHRs and impact on morbidity, mortality, and cost, and use multiple and mixed methods to better understand the impact of PHRs as health information systems [24].

\section{Potentially PHR sensitive conditions}

From this review, there is early evidence that highlights a small group of conditions that have evidence of benefit to using a PHR as a health intervention. These conditions include: diabetes, hypertension, asthma, HIV, fertility management, glaucoma, and hyperlipidemia. Benefits were seen in care quality, access, and/or productivity. These conditions share several common characteristics: Each of these conditions is chronic. They have a significant benefit from self-management through behavioural changes. Many have an aspect of monitoring, either from the clinician or the patient (self-monitoring). Self-management is present in all. The seven conditions were conditions where the self-management behaviours could be suitably tracked in a PHR and were tightly linked to the feedback of monitoring/self-monitoring of indicators (Figure 3). For example, self-monitoring blood pressure in hypertension or glucose levels in diabetes allowed for more specific and direct feedback to patients using a PHR.

Given the early state of the evidence for PHRs, it is not possible to exclude other conditions from this list and, indeed, many of the other conditions that have been evaluated but did not show benefit (e.g. Cancer) have several similar traits to the other conditions that have supporting evidence. It is expected that the PHR design, implementation of the PHR in the context of those patients or the design of the study had an impact on discovering benefits. That is, if the patient or the health condition was not as well supported by the particular 


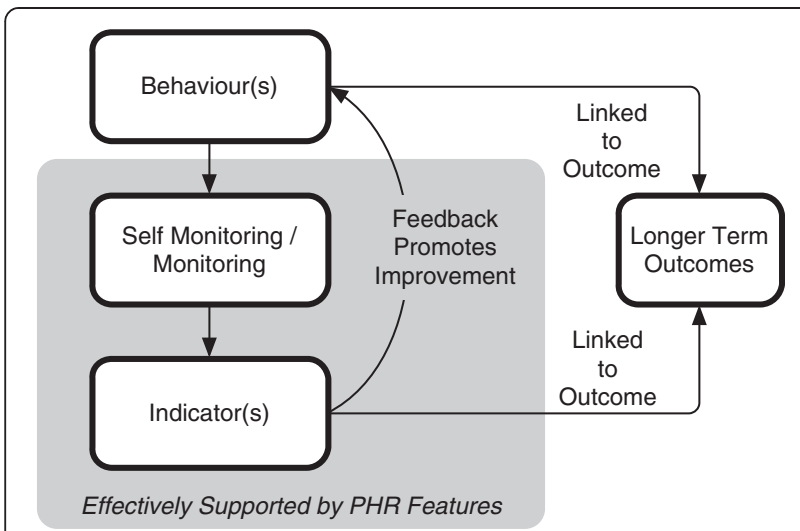

Figure 3 A model to describe how a PHR supports the monitoring of an indicator that promotes an effective behaviour change. If this loop is linked to a meaningful outcome and can be sustained, it can result in improvement outcomes.

PHR or the implementation was different, benefits may not have been seen. Further, other health conditions could benefit from PHRs that have not been examined in studies included in this review. For example, obesity was not found in this this review but has significant prevalence $[25,26]$ and results in elevated risk for specific conditions and morbidity $[27,28]$. Measurements such as body size measurements (e.g. waist size) and fat mass measurements can be used to monitor the impact of behavioural changes on obesity. It could benefit from PHR support. Indeed, there are several self-management applications that are providing tools for weight management such as: SapoFit [29] and over 200 smart phone apps [30].

\section{Contribution to knowledge}

This work expands on Logue's PHR adoption model, providing additional information on the chronic disease factors that influence PHR adoption [6]. The PHR activities list (Table 2) can serve as a model that can be mapped back to the management of other chronic conditions to help in the design and use of PHRs in the future. PHRs today have a range of features/value propositions [10].

For PHR designers and implementers, this condition list can serve as optional target populations (Figure 3) and can be used when considering PHR features. Designers can consider specific feedback loops for health conditions and consider how specific PHRs support PHR enabled care activities such as accessing health information, communicating with providers, and accessing and recording personal health information. Implementers can use the same model when considering how to implement a PHR within a healthcare system.

\section{Study limitations}

Electronic PHRs are new and thus the evidence base is also new, with few studies and no large, long-term studies.
Also, PHRs are different and changing, and new features, such as mobile devices and various environmental and personal sensors, are rapidly evolving. These features may well change the value propositions of PHRs. This review may have missed some studies that were not found through its search strategy. For example, there have been PHR related papers published prior to 2008 that were not included. Earlier reviews suggested that PHRs were limited in functionality [31] and we chose to focus on newer studies that may examine more robust PHRs that leverage Internet and mobile technologies. Quality of studies was graded but papers were not excluded based on quality. The studies focused on different aspects of benefit, limiting between-study meta-analysis. Application of a common evaluation framework in future primary studies would help build a common knowledgebase related to PHRs. PHR features and usability of the PHR were not always clear from the published studies, but we know that this will effect the realization of benefits [32]. It is expected that the variability in PHR design of features changes value [10]. Much of this information was not available in the studies. Finally, as a review, the list of conditions is limited to what has been studied and included in the search.

\section{Conclusion}

While many factors can influence the impact of a PHR such as the PHR's function and design, how it is implemented by the patient and by the healthcare system, we discovered some early evidence of benefit for seven health conditions: asthma, diabetes, fertility, glaucoma, HIV, hyperlipidemia, and hypertension. Each of these conditions are chronic in nature and tend to have clear feedback loops of behaviours resulting in changes in indicators that can be better self-monitored through the PHR. However, the current body of evidence for PHRs is small, with studies limited to assessing perceptions of benefit or early indicators. There is a need to continue research into how PHRs are designed, what features they have, how they are adopted as well as studies that assess PHR impact on health outcomes. Longer term and more robust studies are needed, and our current knowledge can guide future research to potentially PHR sensitive conditions.

\section{Competing interests}

The authors declare that they have no competing interests.

\section{Authors' contributions}

MP was primary author of the paper, developing the initial idea, was a primary reviewer of the literature, and led the draft writing. He also acted as a mediator during the review and is the lead researcher on the overall Alberta Personal Health Portal evaluation. NK was one of the three primary reviewers of the literature, summarizing the data from the included papers. PB completed the primary reviewers of the literature, summarizing the data from the included papers. ID reviewed the paper drafts, providing additional content and literature. JW confirmed approach and provided editorial support on the internal drafts of the paper. FL was the senior author, 
confirmed approach and provided editorial support on the internal drafts of the paper. FL is also the senior researcher on the overall PHP evaluation. All authors read and approved the final manuscript.

\section{Acknowledgments}

We would like to thank Alberta Health and the Personal Health Portal (PHP) program who supported our group in evaluating the design and implementation of the PHP and whose funding permitted the research analyst time to complete this review.

\section{Funding}

This work is funded, in part, through the Alberta Health's Personal Health Portal program.

\section{Author details}

${ }^{1}$ Department of Family Practice, University of British Columbia, Vancouver, B.C., Canada. ${ }^{2}$ Health Information Science, University of Victoria, Victoria, B.C., Canada. ${ }^{3}$ Department of Computer Science, University of Victoria, Victoria, B.C., Canada.

Received: 24 October 2014 Accepted: 15 April 2015

Published online: 18 April 2015

\section{References}

1. Archer N, Fevrier-Thomas U, Lokker C, McKibbon KA, Straus SE. Personal health records: a scoping review. J Am Med Inform Assoc. 2011;18:515-22.

2. Agarwal G. Personal health records-an overview of the changing face of family practice. Fam Pract. 2013:30:363-4.

3. Ball MJ, Smith C, Bakalar RS. Personal health records: empowering consumers. J Healthc Inform Manag. 2007;21:76-86

4. Kaelber DC, Jha AK, Johnston D, Middleton B, Bates DW. A research agenda for personal health records (PHRs). J Am Med Inform Assoc. 2008;15:729-36.

5. Tenforde M, Jain A, Hickner J. The value of personal health records for chronic disease management: what do we know? Fam Med. 2011;43:351.

6. Logue MD, Effken JA. Modeling factors that influence personal health records adoption. Comput Informat Nurs. 2012;30(7):354-62.

7. Ko H, Turner T, Jones C, Hill C. Patient-held medical records for patients with chronic disease: a systematic review. BMJ Qual Saf. 2010;19:e41-1.

8. Greenhalgh T, Hinder S, Stramer K, Bratan T, Russell J. Adoption, nonadoption, and abandonment of a personal electronic health record: case study of HealthSpace. BMJ. 2010:341:c5814-3111

9. $\quad$ Tang P, Ash J, Bates D, Overhage J, Sands D. Personal health records: definitions, benefits, and strategies for overcoming barriers to adoption. Adv Physiol Educ. 2006:13:121-6.

10. Johnston D, Kaelber D, Pan EC, Bu D, Shah S, Hook JM, et al. A framework and approach for assessing the value of personal health records (PHRs). AMIA Annu Symp Proc 2007:374-378.

11. Goldzweig CL, Towfigh AA, Paige NM, Orshansky G, Haggstrom DA, Beroes $J M$, et al. Systematic Review: Secure Messaging Between Providers and Patients, and Patients' Access to Their Own Medical Record: Evidence on Health Outcomes, Satisfaction, Efficiency and Attitudes. Washington (DC): Department of Veterans Affairs (US); 2012.

12. Saberi $P$, Johnson MO. Technology-based self-care methods of improving antiretroviral adherence: a systematic review. PLoS One. 2011;6:e27533.

13. Johansen MA, Henriksen E, Horsch A, Schuster T, Berntsen GKR. Electronic symptom reporting between patient and provider for improved health care service quality: a systematic review of randomized controlled trials. Part 1: state of the art. J Med Internet Res. 2012;14:e118.

14. Ennis L, Rose D, Callard F, Denis M, Wykes T. Rapid progress or lengthy process? electronic personal health records in mental health. BMC Psychiatry. 2011;11:117.

15. Koch S, Vimarlund V. Critical advances in bridging personal health informatics and clinical informatics. Yearb Med Inform. 2012;7(1):48-55.

16. Hordern A, Georgiou A, Whetton S, Prgomet M. Consumer e-health: an overview of research evidence and implications for future policy. HIM J. 2011:40:6-14.

17. Merlin T, Weston A, Tooher R. Extending an evidence hierarchy to include topics other than treatment: revising the Australian 'levels of evidence'. BMC Med Res Methodol. 2009:9:34
18. Solomon M, Wagner SL, Goes J. Effects of a web-based intervention for adults with chronic conditions on patient activation: online randomized controlled trial. J Med Internet Res. 2012;14:e32.

19. Sobko H. Associations Among Measures Of Engagement With Kp.Org And Clinical Outcomes. Birmingham: University of Alabama; 2011. p. 1-239.

20. Grant RW, Wald JS, Schnipper JL, Gandhi TK, Poon EG, Orav EJ, et al. Practice-linked online personal health records for type 2 diabetes mellitus: a randomized controlled trial. Arch Intern Med. 2008;168:1776-82.

21. Urowitz S, Wiljer D, Dupak K, Kuehner Z, Leonard K, Lovrics E, et al. Improving diabetes management with a patient portal: a qualitative study of diabetes self-management portal. J Med Internet Res. 2012;14:e158.

22. Black AD, Car J, Pagliari C, Anandan C, Cresswell K, Bokun T, et al. The impact of eHealth on the quality and safety of health care: a systematic overview. PLoS Med. 2011;8:e1000387.

23. Lau F, Kuziemsky C, Price M, Gardner J. A review on systematic reviews of health information system studies. J Am Med Inform Assoc. 2010;17:637-45.

24. Kaplan B. Evaluating informatics applications-some alternative approaches: theory, social interactionism, and call for methodological pluralism. Int J Med Inform. 2001;64:39-56.

25. Ogden CL, Carroll MD, Curtin LR, McDowell MA, Tabak CJ, Flegal KM. Prevalence of overweight and obesity in the United States, 1999-2004. JAMA. 2006;295:1549-55.

26. Flegal KM, Carroll MD, Kit BK, Ogden CL. Prevalence of obesity and trends in the distribution of body mass index among US adults, 1999-2010. JAMA 2012;307:491-7.

27. Matthias Lenz TRIM. The morbidity and mortality associated with overweight and obesity in adulthood: a systematic review. Dtsch Arztebl Int 2009:106:641.

28. Reilly JJ, Kelly J. Long-term impact of overweight and obesity in childhood and adolescence on morbidity and premature mortality in adulthood: systematic review. Int J Obes Relat Metab Disord. 2010;35:891-8.

29. Rodrigues JJPC, Lopes IMC, Silva BMC, de Torre I L. A new mobile ubiquitous computing application to control obesity: SapoFit. Inform Health Soc Care. 2013;38:37-53.

30. Breton ER, Fuemmeler BF, Abroms LC. Weight loss - there is an app for that! But does it adhere to evidence-informed practices? Behav Med Pract Policy Res. 2011;1:523-9.

31. Kim Ml, Johnson KB. Personal health records: evaluation of functionality and utility. J Am Med Inform Assoc. 2002;9:171-80.

32. Lau F, Hagens $S$, Muttitt S. A proposed benefits evaluation framework for health information systems in Canada. Healthc Q. 2007;10:112-6-118.

33. Wiljer D, Leonard KJ, Urowitz S, Apatu E, Massey C, Quartey NK, et al. The anxious wait: assessing the impact of patient accessible EHRs for breast cancer patients. BMC Med Inform Decis Mak. 2010;10:46.

34. Wade-Vuturo AE, Mayberry LS, Osborn CY. Secure messaging and diabetes management: experiences and perspectives of patient portal users. J Am Med Inform Assoc. 2013:20:519-25.

35. Tenforde M, Nowacki A, Jain A, Hickner J. The association between personal health record use and diabetes quality measures. J Gen Intern Med. 2011;27:420-4.

36. Wald JS, Businger A, Gandhi TK, Grant RW, Poon EG, Schnipper JL, et al. Implementing practice-linked pre-visit electronic journals in primary care: patient and physician use and satisfaction. J Am Med Inform Assoc. 2010;17:502-6.

37. Hess R, Fischer GS, Sullivan SM, Dong X, Weimer M, Zeith C, et al. Patterns of response to patient-centered decision support through a personal health record. Telemed e Health. 2014;20:984-9.

38. Fonda SJ, McMahon GT, Gomes HE. Changes in diabetes distress related to participation in an internet-based diabetes care management program and glycemic control. J Diabet Sci Technol. 2009;3(1):117-24.

39. Lau M, Campbell H, Tang T, Thompson DJS, Elliott T. Impact of patient use of an online patient portal on diabetes outcomes. Can J Diabetes. 2014;38:17-21.

40. Sarkar U, Lyles CR, Parker MM, Allen J, Nguyen R, Moffet HH, et al. Use of the refill function through an online patient portal is associated with improved adherence to statins in an integrated health system. Med Care. 2014;52:194-201

41. Wald JS, Grant RW, Schnipper JL, Gandhi TK, Poon EG, Businger AC, et al. Survey analysis of patient experience using a practice-linked PHR for type 2 diabetes mellitus. AMIA Annu Symp Proc. 2009;2009:678-82.

42. van Empel IWH, Hermens RPMG, Akkermans RP, Hollander KWP, Nelen WLDM, Kremer JAM. Organizational determinants of patient-centered fertility care: a multilevel analysis. Fertil Steril. 2011;95:513-9. 
43. Boland MV, Chang DS, Frazier T, Plyler R, Jefferys JL, Friedman DS, Automated telecommunication-based reminders and adherence with once-daily glaucoma medication dosing: the automated dosing reminder study. JAMA Ophthalmol. 2014;132:845-50.

44. Crouch P-C. Patient Activation in HIV-Infected Veterans Who Use Electronic Personal Health Records. San Francisco: University of California; 2014. p. 1-77.

45. Gordon P, Camhi E, Hesse R, Odlum M, Schnall R, Rodriguez M, et al. Processes and outcomes of developing a continuity of care document for use as a personal health record by people living with HIV/AIDS in New York City. Int J Med Inform. 2012;81:e63-73.

46. Kahn JS, Hilton JF, Van Nunnery T, Leasure S, Bryant KM, Hare CB, et al. Personal health records in a public hospital: experience at the HIV/AIDS clinic at San Francisco General Hospital. J Am Med Inform Assoc. 2010;17:224-8

47. McInnes DK, Shimada SL, Rao SR, Quill A, Duggal M, Gifford AL, et al. Personal health record use and its association with antiretroviral adherence: survey and medical record data from 1871 US veterans infected with HIV. AIDS Behav. 2013;17:3091-100.

48. Shade SB, Steward WT, Koester KA, Chakravarty D, Myers JJ. Health information technology interventions enhance care completion, engagement in HIV care and treatment, and viral suppression among HIVinfected patients in publicly funded settings. J Am Med Inform Assoc 2014

49. Wagner PJ, Dias J, Howard S, Kintziger KW, Hudson MF, Seol Y-H, et al. Personal health records and hypertension control: a randomized trial. J Am Med Inform Assoc. 2012;19:626-34.

50. Chiche L, Brescianini A, Mancini J, Servy H, Durand J-M. Evaluation of a prototype electronic personal health record for patients with idiopathic thrombocytopenic purpura. Patient Preference and Adherence. 2012;6:725-34.

51. Miller DM, Moore SM, Fox RJ, Atreja A, Fu AZ, Lee J-C, et al. Web-based self-management for patients with multiple sclerosis: a practical, randomized trial. Telemed e Health. 2011;17:5-13.

\section{Submit your next manuscript to BioMed Central and take full advantage of:}

- Convenient online submission

- Thorough peer review

- No space constraints or color figure charges

- Immediate publication on acceptance

- Inclusion in PubMed, CAS, Scopus and Google Scholar

- Research which is freely available for redistribution 